\title{
Proximate Composition and Meat Quality of Broilers Reared under Different Production Systems
}

\section{-Author(s)}

Souza XR

Faria $\mathrm{PB}^{2}$

Bressan $\mathrm{MC}^{3}$

1 IFMT Campus São Vicente. Santo Antonio do Leverger, MT, Brasil.

2 Departamento de Medicina Veterinária, Universidade Federal de Lavras. Lavras, MG, Brasil.

3 Instituto Nacional de Investigação Agrária. Vale do Santarém, Portugal.

\section{-Mail Adress}

PB Faria

Departamento de Medicina Veterinária

Universidade Federal de Lavras

Caixa Postal 3037

37.200-000. Lavras, MG, Brasil.

E-mail: peterbfvet@yahoo.com.br

\section{-Keywords}

Free-range chickens, meat quality, proximate composition.

\section{-Acknowledgements}

The authors thank CAPES, CNPq, and FAPEMAT for the scholarships granted; Instituto Federal de Educação, Ciência e Tecnologia de Mato Grosso, São Vicente campus, for supporting the conduction of the experiment, providing facilities and feeds; and Aves do Paraíso Farm for providing the birds.

\begin{abstract}
In this study, the physical-chemical characteristics and proximate composition of the meat of of two strains of broilers (Paraíso Pedrês and Máster gris plumé - Super Pesadão, utilized for semi-intensive rearing) and $\mathrm{Cobb}^{\circledR}$ strain, utilized in intensive rearing systems) were evaluated. Differences related to strain and sex (males and females) were studied. $\mathrm{Cobb}^{\circledR}$ broilers were slaughtered at 45 days and the other strains at 85 days. The following characteristics were evaluated in breast and thigh meat: moisture, protein, ether extract, ashes, color $\left(\mathrm{CIEL}^{*}{ }^{*} \mathrm{~b}^{*}\right)$, final $\mathrm{pH}$, cooking loss (CL) and shear force (SF). Bird strain and sex influenced breast color parameters, with $\mathrm{Cobb}^{\circledR}$ presenting higher yellowness $\left(\mathrm{b}^{\star}\right)$ and redness $\left(a^{*}\right)$ means, whereas females had higher $b^{*}$ values and males, $a^{*}$ values. Paraíso Pedrês had lower SF values. As to proximate composition, there was an interaction between strain and sex, with higher ether extract values in the meat of Super Pesadão males. Cobb ${ }^{\circledR}$ birds presented higher lightness $\left(L^{*}\right)$ and $b^{*}$ values, and there was no effect of sex on color parameters. Higher $\mathrm{pH}$ and SF values were found in the meat of Super Pesadão birds. There was an interaction between strain and sex for $b^{*}$ and SF values, with higher $b^{*}$ values obtained with $\mathrm{Cobb}^{\circledR}$ males, while differences between sex, with superiority for females in the Paraíso Pedrês strain and for males in the Cobb ${ }^{\circledR}$ strain were found. Increased values of SF for males were obtained for Super Pesadão strain. Both Paraíso Pedrês and Super Pesadão strains presented physicochemical and proximate composition characteristics similar to those of $\mathrm{Cobb}^{\circledR}$ strain in the cuts breast and thigh so that in a few parameters, no differences between the birds kept in this two rearing systems were found.
\end{abstract}

\section{INTRODUCTION}

Although genetic improvement has led to higher productivity in domestic species, these advances have only immediate economic importance and disregard long-term issues, such as the sustainability of production systems and the increasing demands of consumers as to the origin of the food they buy. The failure to include meat quality parameters in the selection criteria of domestic animals resulted in the emergence of abnormalities, such as PSE (pale, soft, and exudative meat) and DFD (dark, firm, and dry meat), affecting modern breeds of pigs, broilers, cattle, and turkeys. The development of broiler strains with the purpose of providing birds with features closer to the original breeds to alternative production systems may contribute for the reduction of biochemical meat abnormalities (e.g., PSE) that have been currently shown in studies with broiler strains reared in conventional industrial systems.

The production chain acknowledges the importance of food sensorial attributes as a decision-making factor when consumers make 
their purchase (Farmer et al., 1997). Therefore, farmers should adopt measures to maintain those attributes or to adopt strategies to develop the desired features in the final product.

The breeds and strains of birds used in alternative systems usually have poor genetic growth potential, are very hardy and well-adapted to extensive farming. The main birds used in alternative systems in Brazil are Colonial 041 (EMBRAPA-CNPSA), Caipirinha da ESALQ (USP), Paraíso Pedrês (Aves do Paraíso farm), Barred Plymouth Rock ${ }^{\circledR}$, and some strains imported from France (HUBBARD-ISA ${ }^{\circledR}$ and SASSO ${ }^{\circledR}$ ), such as Redbro cou nu and Redbro plumé, also known as pesadão; Gris Barre Plumé, known as carijó; and Master gris plumé, also known as Super Pesadão (Souza, 2004).

Free-range broiler production systems are regulated in Brazil by DIPOA (Department of Inspection of Products of Animal Origin - Departamento de Origem de Produtos de Origem Animal) provision number 007/99, which recommends the use of slow-growing strains adapted to the system; minimal slaughter age of 85 days; access to a pasture area with at least $3 \mathrm{~m}^{2} /$ bird; feeds based exclusively on plant feedstuffs, and the use of antibiotic growth promoters is not allowed.

The production of broilers in free-range systems is may provide determined meat traits sought by consumers of chicken meat. The main differences in meat quality attributes between free-range and conventionally-reared chickens are related to color, flavor, and texture "(Castellini et al., 2002a; Castellini et al., 2002b; Castellini, 2005; Rizzi, 2007). These differences may be related to sex, due to the different growth and muscle development potential between males and females (Le Bihan-Duval, 2004; Farmer et al., 1997; Santos et al., 2005; Toldrá, 2003; Touraille et al., 1981). However, the effects of different genetic strains on meat quality characteristics are not well known, particularly in slow-growing strains.

The objective of the present study was to evaluate the quality and the physical-chemical characteristics of the meat of two strains developed for free-range production systems (Paraíso Pedrês and Super Pesadão) and to compare them to a strain $\left(\mathrm{Cobb}^{\circledR}\right)$ developed for conventional rearing systems according to sex (males or females).

\section{MATERIAL AND METHODS}

The experiment was conducted at the Federal Institute of Education, Science and Technology of Mato Grosso, São Vicente Campus, Brazil. A flock of
72 birds was used, with 24 males and females of two free-range broiler strains (Super Pesadão and Paraíso Pedrês) and one conventional broiler strain $\left(\mathrm{Cobb}^{\circledR}\right)$. Free-range chickens were slaughtered at 85 days of age, and the conventional broilers were slaughtered at 45 days.

A completely randomized experimental design was applied, using a $3 \times 2 \times 4$ factorial arrangement with three strains (Super Pesadão, Paraíso Pedrês, and $\left(\mathrm{Cobb}^{\circledR}\right)$, two sexes (males and females), and four replicates per treatment, totaling 72 experimental units. One experimental unit consisted of three birds.

Diet was formulated for two growing phases (Table 1). The starter diet was fed for the first 28 days and the finisher diet from day 29 up to slaughter. Free-range birds were reared from 1 to 28 days in pens, with free access to feed and water, and from 29 to 85 days in a shed with access to a grazing area at a density of more than $3 \mathrm{~m}^{2} /$ bird.

Birds were humanely slaughtered by mechanical stunning (contusion at the region of the occipital and atlas bones), followed by cutting of the blood vessels (carotid artery and jugular vein). After evisceration, carcasses were packed, identified, and chilled to $0{ }^{\circ} \mathrm{C}$. Cuts were deboned 24 hours post mortem, packed, identified, frozen, and stored at $-18^{\circ} \mathrm{C}$. Meat physicalchemical analyses were performed after cuts were thawed at $4{ }^{\circ} \mathrm{C}$ for $24 \mathrm{~h}$.

Final $\mathrm{pH}$ was determined using a DIGIMED DM-20 pHmeter coupled to a probe placed in incisions made with the tip of a knife in the cranial right side of the breast and in the upper front side of the right thigh.

Color was determined using a MINOLTA CR 200b colorimeter (Osaka, Japan), operating in the CIEL ${ }^{*} a b^{*}$ system with D65 illuminant. Readings were made at three different areas of the internal face of the cranial position of the left pectoralis major muscle in the breast and of the internal face the fibular longus muscle in the thighs (Souza, 2004). Meat samples were exposed to light for 30 minutes before readings. The values of the color components used for statistical analyses were the averages of the three readings performed per cut per bird in each experimental unit.

Cooking loss $(\mathrm{CL})$ was determined in breast and thigh samples used for color determination. Samples were weighed in semi-analytical scales (METTLER M P1210, Toledo, Brazil), involved in aluminum foil, and cooked on an electric griddle at $150^{\circ} \mathrm{C}$. When meat temperature reached $72^{\circ} \mathrm{C}$, samples were removed from the griddle, let to cool to room temperature, and weighed (Amasa, 1978; Bressan, 1998; Bressan et 
al., 2004; Souza, 2004; Faria, 2009). Averages values of the weight difference before and after cooking of breast and thigh samples per experimental unit were converted in percentages and submitted to statistical analysis.

Table 1 - Ingredients and calculated and analyzed composition of starter and finisher diets fed to free-range and conventional chickens.

\begin{tabular}{|c|c|c|}
\hline Ingredients & $\begin{array}{l}\text { Starter diet } \\
\text { (\%) }\end{array}$ & $\begin{array}{c}\text { Finisher diet } \\
(\%)\end{array}$ \\
\hline Ground corn & 63.00 & 70.00 \\
\hline Soybean meal (45\%) & 33.70 & 27.00 \\
\hline Dicalcium phosphate & 2.00 & 1.80 \\
\hline Calcitic limestone & 0.85 & 0.75 \\
\hline Salt $(\mathrm{NaCl})$ & 0.30 & 0.25 \\
\hline Vitamin and mineral supplement & 0.35 & 0.20 \\
\hline \multicolumn{3}{|l|}{ Calculated values } \\
\hline True metabolizable energy $(\mathrm{kcal} / \mathrm{kg})$ & 2,896 & 2,972 \\
\hline Methionine + cystine (\%) & 0.70 & 0.64 \\
\hline Lysine (\%) & 1.13 & 0.97 \\
\hline Methionine (\%) & 0.34 & 0.30 \\
\hline \multicolumn{3}{|l|}{ Analyzed values (\%) } \\
\hline Moisture & 13.90 & 13.95 \\
\hline Crude protein & 21.50 & 18.25 \\
\hline Ether extract & 4.02 & 3.64 \\
\hline Ashes & 4.98 & 4.72 \\
\hline Crude fiber & 3.42 & 3.12 \\
\hline NDF (Neutral detergent fiber) & 15.60 & 16.80 \\
\hline ADF (Acid detergent fiber) & 7.20 & 7.80 \\
\hline Nitrogen-free extract & 52.32 & 56.66 \\
\hline Calcium & 1.22 & 1.36 \\
\hline Phosphorus & 0.66 & 0.63 \\
\hline Magnesium & 0.17 & 0.18 \\
\hline \multicolumn{3}{|c|}{ 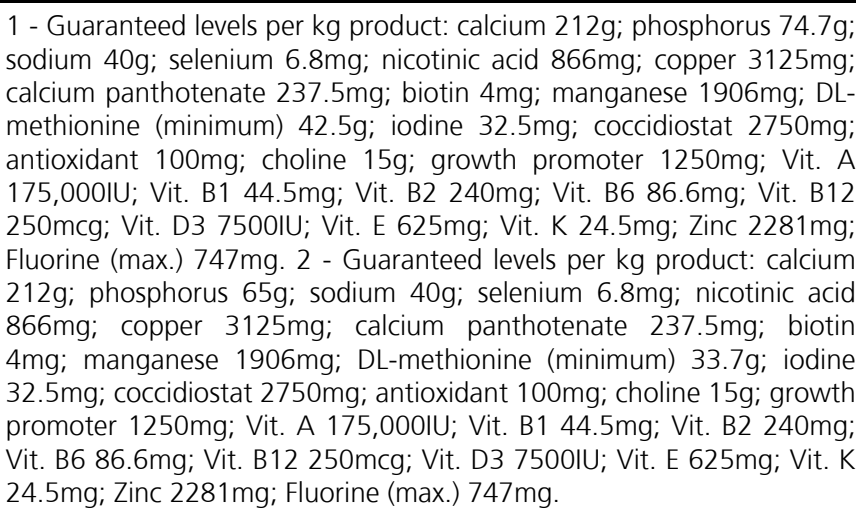 } \\
\hline
\end{tabular}

Samples used for $\mathrm{CL}$ determination were prepared for shear force (SF) or tenderness evaluation. The cooked samples were cut into $2.0 \times 1.0 \times 1.0 \mathrm{~cm}$ pieces, with the longest length lengthwise to the muscle fibers, according to the methodology of Froning \& Uijttenboogarte (1988) and Castellini et al., 2002. Samples were cut transversally to the muscle fibers using a Warner-Bratzler apparatus coupled to a texturometer (model TA XT-2) calibrated to a cutting speed of $2 \mathrm{~mm} / \mathrm{s}$, sensitivity of $0.250 \mathrm{~N}$ and in $\mathrm{kg} / \mathrm{cm}^{2}$ units.

Skin and aponeuroses were removed from breast and thigh samples, which were then homogenized and submitted proximate analysis. Moisture, protein, ether extract, and ash were analyzed in triplicate and carried out according to Horwitz (1990).

Data were analyzed using SISVAR software program (Ferreira, 2000). Means were compared by the test of Tukey at 5\% significance level.

\section{RESULT AND DISCUSSION}

Breast lightness $\left(L^{*}\right)$ values were not influenced by genetic strain or sex. However, redness $\left(a^{*}\right)$ and yellowness $\left(b^{*}\right)$ in $\mathrm{Cobb}^{\circledR}$ meat samples were higher than in Super Pesadão and Paraíso Pedrês meat, and males presented higher redness and lower yellowness values as compared to females. According to Qiao et al. (2002), pre-slaughter management and genetic predisposition are the main factors that influence meat color. The effect of pre-slaughter management on meat color is related to $\mathrm{pH}$, which directly influences the capacity of myoglobin to express the red color and to bind to water (Castelinni et al., 2002). In the present study, $\mathrm{pH}$ values were very similar among the treatments, resulting in similar lightness $\left(L^{*}\right)$ values among treatments. The differences in redness $\left(a^{*}\right)$ values among strains, taking into account the absence of $\mathrm{pH}$ difference, can be ascribed to the genetic traits.

Average breast $\mathrm{pH}$ values were not affected by genetic strain or sex. The breast is composed of glycolytic muscles, which are not often used in movements performed by the bird during the preslaughter period. In addition, the experimental birds did not suffer transportation stress and were submitted to the same pre-slaughter management conditions. These conditions possibly influenced the uniformity of the $\mathrm{pH}$ values found among the treatments in the present study. Literature reports results that are consistent with the findings of the present study (Lonergan et al., 2003; Quentin et al., 2003 and Santos et al., 2005).

Mean breast $C L$ was not influenced by genetic strain and sex. CL values may be influenced by $\mathrm{pH}$ and lipid content of the evaluated muscle (Forrest, 1979; Souza, 
2004). In the present study, differences in $\mathrm{pH}$ and lipid content were not sufficient to influence $C L$ values.

SF values were affected by genetic strain, with Paraíso Pedrês presenting the lowest SF (Table 2). Chicken breast meat tenderness can suffer the phenomenon of PSE (Bressan, 1998). The uniformity of $\mathrm{pH}$ values rules out the possibility of PSE occurrence in the evaluated treatments, which possibly accounts for the small differences among the shear force values found in the present study.

Meat proximate composition was not influenced by genetic strain; however, ash content was affected by sex, with the highest values obtained in males (Table 2). Ashes indicate muscle mineral content. These minerals are associated to the organic compounds involved in the muscle contraction process, and its values increase as the animal grows (Prändl et al., 1994). Males present higher ash content as their muscle tissue percentage values is higher as compared to females.

Breast ether extract was affected by the interaction between sex and genetic strain $(p<0.05)$, with Super Pesadão males presenting the highest values (Table 3 ). On the other hand, Lonergan et al. (2003) reported higher ether extract values in females as influenced by the interaction between sex and genetic group. In the present study, it was not expected that the breast meat of males presented higher ether extract content. Taking into account the high coefficients of variation of ether extract data (Table 2), further studies are required to determine if that difference can be truly ascribed to the effect of the treatment.

Table 3 - Mean ether extract values of chicken breasts as a function of genetic strain and sex.

\begin{tabular}{|l|c|c|}
\hline \multirow{2}{*}{ Strains } & \multicolumn{2}{|c|}{ Sex } \\
\cline { 2 - 3 } & Males & Females \\
\hline Super Pesadão & $0.90^{\mathrm{aA}}$ & $0.57^{\mathrm{bA}}$ \\
\hline Paraíso Pedrês & $0.62^{\mathrm{aB}}$ & $0.74^{\mathrm{aA}}$ \\
\hline Cobb $^{\circledR}$ & $0.72^{\mathrm{aB}}$ & $0.63^{\mathrm{aA}}$ \\
\hline
\end{tabular}

Means followed by different capital letters in the same column and different small letters in the same row are different by the test of Tukey $(\mathrm{p}<0.05)$.

In thigh meat, color parameters were affected by genetic strain, with $\mathrm{Cobb}^{\circledR}$ birds presenting higher $L^{*}$ and $b^{*}$ value and lower $a^{*}$ values (Table 4). Low $\mathrm{pH}$ values affect meat protein biochemistry, resulting in higher lightness and redness and lower yellowness (Castelinni et al., 2002). This was confirmed by the relation between $\mathrm{pH}$ and color parameters in $\mathrm{Cobb}^{\circledR}$ and Super Pesadão strains; however, despite presenting $\mathrm{pH}$ values similar to $\mathrm{Cobb}^{\circledR}$, Paraíso Pedrês had different color values. Genetic factors possibly have higher influence on color parameters than $\mathrm{pH}$ in Paraíso Pedrês meat. The effect of genotype on color parameters was reported by several authors, including Berri et al. (2005), Castellini et al. (2002b), Grashorn \& Clostermann (2002), and Quentin et al. (2003). When tissues (breast and thighs) were compared as to redness $\left(a^{*}\right)$, it was found that $\mathrm{Cobb}^{\circledR}$ birds presented higher $a^{*}$ values in the breast as compared to the free-range strains (Table 2). On the other hand, higher $a^{*}$ values were found in the thighs of free-range birds (Paraíso Pedrês and Super Pesadão). This apparent inconsistency may be due to bird movement, as birds

Table 2 - Mean meat quality trait values and proximate composition chicken breast as a function of genetic strain and sex.

\begin{tabular}{|l|c|c|c|c|c|c|}
\hline \multirow{2}{*}{ Color } & \multicolumn{3}{|c|}{ Strains } & \multicolumn{2}{c|}{ Sex } & \multirow{2}{*}{ CV } \\
\cline { 2 - 6 } & Super Pesadão & Paraíso Pedrês & Cobb & Male & Female & (\%) \\
\hline $\mathrm{L}^{*}$ & $46.62^{\mathrm{a}}$ & $46.75^{\mathrm{a}}$ & $46.76^{\mathrm{a}}$ & $46.46^{\mathrm{a}}$ & $46.96^{\mathrm{a}}$ & 4.58 \\
\hline $\mathrm{a}^{\star}$ & $4.76^{\mathrm{b}}$ & $4.16^{\mathrm{b}}$ & $6.12^{\mathrm{a}}$ & $5.38^{\mathrm{a}}$ & $4.64^{\mathrm{b}}$ & 13.50 \\
\hline $\mathrm{b}^{\star}$ & $6.69^{\mathrm{b}}$ & $6.33^{\mathrm{b}}$ & $7.87^{\mathrm{a}}$ & $6.62^{\mathrm{b}}$ & $7.31^{\mathrm{a}}$ & 11.55 \\
\hline $\mathrm{pH}$ & $5.78^{\mathrm{a}}$ & $5.70^{\mathrm{a}}$ & $5.80^{\mathrm{a}}$ & $5.76^{\mathrm{a}}$ & $5.76^{\mathrm{a}}$ & 1.62 \\
\hline $\mathrm{CL}^{1}$ & $30.18^{\mathrm{a}}$ & $29.28^{\mathrm{a}}$ & $29.63^{\mathrm{a}}$ & $29.69^{\mathrm{a}}$ & $29.70^{\mathrm{a}}$ & 4.77 \\
\hline $\mathrm{SF}^{2}$ & $2.12^{\mathrm{a}}$ & $1.92^{\mathrm{b}}$ & $2.09^{\mathrm{a}}$ & $2.08^{\mathrm{a}}$ & $2.00^{\mathrm{a}}$ & 6.02 \\
\hline Proximate composition & $75.26^{\mathrm{a}}$ & $75.62^{\mathrm{a}}$ & $75.57^{\mathrm{a}}$ & $75.60^{\mathrm{a}}$ & $75.37^{\mathrm{a}}$ & 0.74 \\
\hline Moisture & $22.61^{\mathrm{a}}$ & $22.48^{\mathrm{a}}$ & $22.49^{\mathrm{a}}$ & $22.35^{\mathrm{a}}$ & $22.70^{\mathrm{a}}$ & 2.38 \\
\hline Protein & $0.73^{\mathrm{a}}$ & $0.68^{\mathrm{a}}$ & $0.67^{\mathrm{a}}$ & $0.75^{\mathrm{a}}$ & $0.65^{\mathrm{a}}$ & 18.26 \\
\hline Ether extract & $0.95^{\mathrm{a}}$ & $1.00^{\mathrm{a}}$ & $0.96^{\mathrm{a}}$ & $1.01^{\mathrm{a}}$ & $0.93^{\mathrm{b}}$ & 8.49 \\
\hline Ashes & 0.5 &
\end{tabular}

Means followed by different small letters in the same row are different by the test of Tukey $(p<0.05) .1$ - Cooking loss. 2 - Shear force. reared in free-range systems graze and perform more exercises, changing muscle metabolism, with higher development of red muscle fibers (Erickson, 1996).

The analysis of thigh $\mathrm{pH}$ values showed differences among strains, with higher values for Super Pesadão birds as compared to Paraíso Pedrês and Cobb ${ }^{\circledR}$. Broiler strains reared in alternative systems are more adapted to movement, and therefore, present higher capacity of reacting to pre-slaughter management. This may have lead to higher glycogen muscle consumption during the pre-slaughter period, reducing meat acidifying capacity. The differences found between $\mathrm{Cobb}^{\circledR}$ and Super Pesadão strains are consistent with that physiological behavior. 
Table 4 - Mean meat quality trait values and proximate composition chicken thighs as a function of genetic strain and sex.

\begin{tabular}{|l|c|c|c|c|c|c|}
\hline \multirow{2}{*}{ Color } & \multicolumn{3}{|c|}{ Strains } & \multicolumn{2}{c|}{ Sex } & \multirow{2}{*}{$\begin{array}{c}\text { CV } \\
\text { (\%) }\end{array}$} \\
\cline { 2 - 6 } & Super Pesadão & Paraíso Pedrês & Cobb & Male & Female & \\
\hline $\mathrm{L}^{*}$ & $43.57^{\mathrm{b}}$ & $42.81^{\mathrm{b}}$ & $45.77^{\mathrm{a}}$ & $44.01^{\mathrm{a}}$ & $44.10^{\mathrm{a}}$ & 2.16 \\
\hline $\mathrm{a}^{*}$ & $12.63^{\mathrm{a}}$ & $13.45^{\mathrm{a}}$ & $11.78^{\mathrm{b}}$ & $12.42^{\mathrm{a}}$ & $12.82^{\mathrm{a}}$ & 6.43 \\
\hline $\mathrm{b}^{*}$ & $8.22^{\mathrm{b}}$ & $8.22 \mathrm{~b}$ & $8.86^{\mathrm{a}}$ & $8.46^{\mathrm{a}}$ & $8.41^{\mathrm{a}}$ & 5.87 \\
\hline $\mathrm{pH}$ & $6.14^{\mathrm{a}}$ & $5.97 \mathrm{~b}$ & $5.96^{\mathrm{b}}$ & $6.03^{\mathrm{a}}$ & $6.02^{\mathrm{a}}$ & 1.51 \\
\hline $\mathrm{CL}^{1}$ & $32.73^{\mathrm{a}}$ & $31.82^{\mathrm{a}}$ & $34.11^{\mathrm{a}}$ & $32.68^{\mathrm{a}}$ & $33.09^{\mathrm{a}}$ & 5.18 \\
\hline $\mathrm{SF}^{2}$ & $2.41^{\mathrm{a}}$ & $2.20 \mathrm{~b}$ & $2.17^{\mathrm{b}}$ & $2.38^{\mathrm{a}}$ & $2.13^{\mathrm{b}}$ & 6.57 \\
\hline
\end{tabular}

Proximate composition

\begin{tabular}{|l|c|c|c|c|c|c|}
\hline Moisture & $77.15^{\mathrm{a}}$ & $77.23^{\mathrm{a}}$ & $76.14^{\mathrm{b}}$ & $76.86^{\mathrm{a}}$ & $76.83^{\mathrm{a}}$ & 0.48 \\
\hline Protein & $19.41^{\mathrm{a}}$ & $19.79^{\mathrm{a}}$ & $19.86^{\mathrm{a}}$ & $19.52^{\mathrm{a}}$ & $19.85^{\mathrm{a}}$ & 2.98 \\
\hline Ether extract & $2.85^{\mathrm{a}}$ & $2.65^{\mathrm{a}}$ & $2.88^{\mathrm{a}}$ & $2.87^{\mathrm{a}}$ & $2.72^{\mathrm{a}}$ & 13.97 \\
\hline Ashes & $0.95^{\mathrm{a}}$ & $0.91^{\mathrm{a}}$ & $0.90^{\mathrm{a}}$ & $0.92^{\mathrm{a}}$ & $0.92^{\mathrm{a}}$ & 8.96 \\
\hline
\end{tabular}

Means followed by different in the same row are different by the test of Tukey $(p<0.05) .1$ Cooking loss. 2 - Shear force.

Ultimate $\mathrm{pH}$ values in the thigh muscle were high, close to 6.00. High values were reported by Castellini et al. (2002a), with means ranging between 6.02 and 6.25 and by Souza (2004), with means varying from 5.93 to 6.22 .

There was no effect of genetic strain or sex on $\mathrm{CL}$ (Table 4). Weight loss during cooking may vary due to differences in $\mathrm{pH}$ and lipid content (Forrest, 1979). Thigh meat $\mathrm{pH}$ and lipid content differences observed in the present study possibly were no sufficient to influence $C L$ values. The obtained results are consistent with the findings of Alvarado et al. (2005), who did not find any differences in $\mathrm{CL}$ in the meat of chickens produced in alternative or conventional systems, but further studies are still required to determine the effect of broiler rearing systems on CL. Santos et al. (2005) obtained higher $C L$ values in the meat of conventional chickens relative to those from strains kept in alternative systems. Castellini et al. (2002) observed an opposite result, determining higher $\mathrm{CL}$ values in organic chicken thigh meat as compared to conventional broilers.

Higher SF values were obtained in Super Pesadão birds, while no differences between Paraíso Pedrês and Cobb $^{\circledR}$ birds were observed. Different results were reported by Castellini et al. (2005), who found higher shear force values in breast and thigh meat of two free-range strains with different growth rates (fast and slow) relative to broilers reared in a conventional system. The difference in thigh $\mathrm{pH}$ and tenderness observed between Super Pesadão birds and the other two strains is due to the fact that those birds move more, increasing the oxidative demand of the thigh muscles, which leads to a higher development of structures related to the aerobic respiration, such as red muscle fibers, mitochondria, and myoglobin (Erikson, 1996).

The only meat composition parameter influenced by the treatments was moisture, with lower values obtained in $\mathrm{Cobb}^{\circledR}$ birds, but there was no effect of sex. The similar meat composition between freerange birds (Super Pesadão and Paraíso Pedrês) and conventional birds $\left(\mathrm{Cobb}^{\circledR}\right)$ may be related to the feed restriction system adopted in the free-range system. This management possibly leads to higher energy utilization when birds move to seek feed supplementation by grazing, which may explain the increase in slaughter age with no accumulation of lipids in the meat (Tables 2 and 4). Castellini (2005), working with conventional and organic broiler production systems and feeding birds ad libitum, obtained different meat lipid and moisture contents.

\section{CONCLUSIONS}

The meat of birds of Paraíso Pedrês and Super Pesadão strains, recommended for the use in freerange broiler production systems, presented different physical-chemical characteristics as compared to $\mathrm{Cobb}^{\circledR}$ broilers reared in a conventional system as to redness and yellowness. $\mathrm{Cobb}^{\circledR}$ birds presented higher breast and thigh meat yellowness, whereas Paraíso Pedrês and Super Pesadão birds had higher thigh meat redness, and lower breast meat redness. Meat composition was not influenced by genetic strain or sex. Therefore, under the conditions of the present experiment, there was little influence of genetic strain on the composition and physical-chemical characteristics of breast and thigh meat.

\section{REFERENCES}

Amasa. Guidelines for cooking and sensory evaluation of meat. Chicago; 1978.

Berri C, Debut M Santé-Lhoutellier V, Arnould C, Boutten B, Sellier $N$, Baéza $E$, Jehl $N$, Jégo $Y$, Duclos $M J$, Bihan-Duval $E$ Le. Variations in chicken breast meat quality: implications of struggle and muscle glycogen content at death. British Poultry Science 2005; 46(5):572-579.

Bressan MC. Efeito dos fatores pré e pós-abate sobre a qualidade da carne de peito de frango [tese]. Campinas (SP): Faculdade de 
Souza XR, Faria PB, Bressan MC
Proximate Composition and Meat Quality of Broilers Reared under Different Production Systems

Engenharia de Alimentos, Universidade Estadual de Campinas; 1998.

Bressan MC, Jardim NS, Perez JRO, Thomazini M, Lemos ALSC, Oda SHI, Pisa ACC, Vieira JO, Faria PB, Freitas RTF. Influência do sexo e faixas de peso ao abate nas características físico-químicas da carne de capivara. Ciência e Tecnologia de Alimentos, Campinas 2004; 24(3):357-362.

Castellini C. Organic poultry production system and meat characteristics. XVII European Symposium on the quality of Poultry Meat. Proceedings of the 11th European Symposium on the Quality of Eggs and Egg Products Doorwerth; 2005 may 23-26; The Netherlands.

Castellini C, Dal Bosco A, Mugnai C, Pedrazzoli M. Comparison of two chicken genotypes organically reared: oxidative stability and other qualitative traits of the meat. Italian Journal Animal Science 2006; 5:355-363.

Castellini C, Mugnai C, Dal Bosco A. Effect of organic production system on broiler carcass and meat quality. Meat Science 2002a; 60(3):219-225.

Castellini C, Mugnai C, Dal Bosco A. Meat quality of three chicken genotypes reared according to the organic system. Italian Journal of Food Science 2002b;14:401-424.

Erickson HH. Fisiologia do exercício. In: Swens MJ, Reece WO. Dukes fisiologia dos animais domésticos. Rio de Janeiro: Guanabara; 1996. p.278-296

Fanatico AC, Cavitt LC, Pillai PB, Emmert JL, Owens CM. Evaluation of slower-growing broiler genotype grown with and without outdoor access: meat Quality. Poultry Science 2005; 84:17851790

Faria PB, Bressan MC, Souza XR, Rodrigues EC, Cardoso GP, Telo da Gama L. Composição proximal e qualidade da carne de frangos das linhagens Paraíso Pedrês e Pescoço Pelado. Revista Brasileira de Zootecnia 2009; 38(12):2455-2464.

Farmer LJ, Perry GC, Nute GR, Piggott JR, Patterson RLS. Responses of two genotypes of chicken to the diets and stocking densities of conventional UK and Label Rouge production systems - II. Sensory attributes. Meat Science 1997; 47(1/2):77-93.

Ferreira DF. Analises estatísticas por meio do sisvar para o Windows versão 4.0. Programas e Resumos da $45^{\text {th }}$ Reunião Anual Da Regiao Brasileira Da Sociedade Internacional De Biometria; 2000; São Carlos, São Paulo. Brasil. São Carlos:UFSCar; 2000. p.255-258.

Froning GW, Uijttenboogaart TG. Effect of post mortem electrical stimulation on color, texture, $\mathrm{pH}$ and cooking loses of ho and cold deboned chicken broiler breast meat. Poultry Science 1988; 67(11):1536-1544.

Grashorn MA, Clostermann G. Performance and slaughter characteristics of broiler breeds for extensive production. Arch. Geflügelk 2002; 66(4):173-181.

Horwitz W. Official methods of analysis of Association of Official Analytical Chemists. 15 ${ }^{\text {th }}$ ed. Whashington: AOAC; 1990. p.1278.
Lawrie RA. Ciência da carne. 6th ed. São Paulo: Artmed; 2005.

Le Bihan-Duval E. Genetic variability within and between breeds of poultry technological meat quality. World Poultry Science Journal 2004; 60:331-340.

Lonergan SM, Deeb N, Fedler CA, Jamont SJ. Breast meat quality and composition in unique chicken populations. Poultry Science 2003; 82:1990-1994.

Musa HH,Chen GH, Cheng JH, Shuiep ES, Bao WB. Breed and Sex effect on meat quality of chicken. International Journal Of Poultry Science 2006; 5(6);566-568.

Prändl O, Fischer A, Schmidhofer T, Sinell HJ. Tecnología e hygiene de la carne. Zaragoza: Acribia; 1994.

Quentin M, Bouvarel I, Berri C, Bihan-Duval E, Baeza E, JegoY, Picard M. Growth, carcass composition and meta quality response to dietary concentrations in fast-, medium- and slow-growing commercial broilers. Animal Research 2003;(52):65-77.

Rizzi C, Marangon A, Chiericato GM. Effect o genotype on slaughtering performance and meat physical and sensory characteristics of organic laying hens. Poultry Science 2007; 86:128-135.

Santos AL, Skomura NK, Freitas ER, Sá Fortes CML, Carrilho ENVM, Fernandes JBK. Estudo do crescimento, desempenho, rendimento de carcaça e qualidade de carne de três linhagens de frango de corte. Revista Brasileira de Zootecnia 2005;34(5):1589-1598.

Souza XR. Características de carcaça, qualidade de carne e composição lipídica de frangos de corte criados em sistemas de produção caipira e convencional (tese). Universidade Federal de Lavras (MG); 2004

Takahashi SE, Mendes AA, Saldanha ESPB, Pizzolante CC, Pelicia K, Garcia RG, Paz ICIA, Quinteiro RR. Efeito do sistema de criação sobre o desempenho e rendimento de carcaça de frangos de corte tipo colonial. Arquivos Brasileiros de Medicina Veterinária e Zootecnia 2006; 58(4):624-632.

Toldrá F. Muscle foods: water, structure and functionality. Food Science Tecnology International 2003; 9(3):173-177.

Touraille C, Kopp J, Valin C, Ricard FH. Qualite du poulet. 1 influence de l'age et de la vitesse de croissance sur les caractéristiques physico-chimiques et organoleptiques de la viande. Arch Geflügelk 1981; 45:69-76. 